\title{
Cycle Threshold Values in the Context of Multiple RT-PCR Testing for SARS-CoV-2
}

Risk Management and Healthcare Policy

\section{Daniel Romero-Alvarez (D) \\ Daniel Garzon-Chavez (D) ${ }^{2}$ \\ Franklin Espinosa iD ${ }^{3}$ \\ Edison Ligña ${ }^{3}{ }^{3}$ \\ Enrique Teran (iD ${ }^{2}$ \\ Francisco Mora ${ }^{3}$ \\ Emilia Espin (iD ${ }^{4}$ \\ Cristina Albán ${ }^{4}$ \\ Juan Miguel Galarza (iD) ${ }^{4}$ \\ Jorge Reyes iD $^{3,5}$}

'Biodiversity Institute and Department of Ecology \& Evolutionary Biology, University of Kansas, Lawrence, KS, USA; ${ }^{2}$ Colegio de Ciencias de la Salud, Universidad San Francisco de Quito, Quito, Ecuador; ${ }^{3}$ Departamento Microbiología Médica, Hospital IESS Quito Sur, Quito, Ecuador; ${ }^{4}$ Hospital IESS Carlos Andrade Marin, Quito, Ecuador; ${ }^{5}$ Universidad Central del Ecuador, Quito, Ecuador

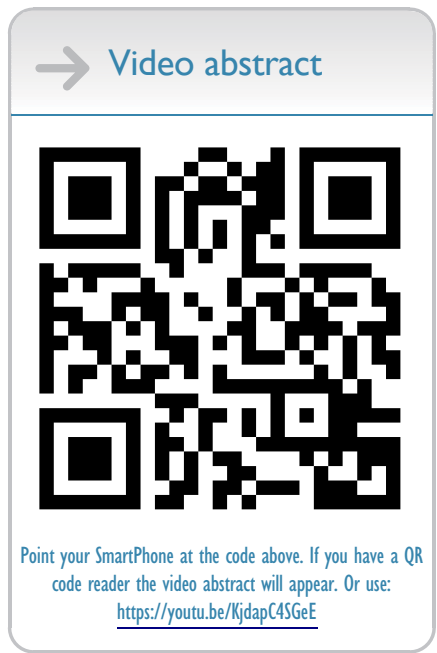

Correspondence: Daniel Garzon-Chavez Colegio de Ciencias de la Salud, Universidad San Francisco de Quito, Diego de Robles s/n y Pampite, Cumbaya, Quito, ECI7090I, Ecuador

Tel +59399862409

Email dgarzonc@usfq.edu.ec

\begin{abstract}
Purpose: Discharge or follow up of confirmed coronavirus disease 2019 (COVID-19) cases depend on accurate interpretation of RT-PCR. Currently, positive/negative interpretations are based on amplification instead of quantification of cycle threshold $(\mathrm{Ct})$ values, which could be used as proxies of patient infectiousness. Here, we measured $\mathrm{Ct}$ values in hospitalized confirmed COVID-19 patients at different times and its implications in diagnosis and follow up.
\end{abstract}

Patients and Methods: Observational study between March 17th-May 12th, 2020 using multiple RT-PCR testing. A cohort of 118 Hispanic hospitalized patients with confirmed COVID-19 diagnosis in a reference hospital in Quito, Ecuador. Multiple RT-PCR tests were performed using deep nasal swab samples and the assessment of SARS-CoV-2 genes N, RdRP, and E.

Results: Patients' median age was of 49 years (range: $24-91)$ with a male majority $(62.7 \%)$. We found increasing levels of $\mathrm{Ct}$ values in time, with a mean $\mathrm{Ct}$ value of $29.13 \mathrm{ln}=61$, standard deviation $(\mathrm{sd})=5.55)$ for the first test and $34.38(\mathrm{n}=60, \mathrm{sd}=4), 35.52(\mathrm{n}=20, \mathrm{sd}=$ $2.85)$, and $36.12(\mathrm{n}=6, \mathrm{sd}=3.28)$, for the second, third, and fourth tests, respectively. Time to RT-PCR lack of amplification for all tests was of 34 days while time to RT-PCR Ct values $>33$ was of 30 days.

Conclusion: Cycle thresholds can potentially be used to improve diagnosis, management and control. We found that turnover time for negativity can be large for hospitalized patients and that $11 \%$ cases persisted with infectious $\mathrm{Ct}$ values for more time than the current isolation recommendations.

Keywords: SARS-CoV-2, coronavirus, pandemic, cycle thresholds, RT-PCR, diagnosis, COVID-19

\section{Introduction}

Since the first cases of coronavirus disease-2019 (COVID-19) were detected in Latin America in late February 2020, the severe acute respiratory syndrome coronavirus 2 (SARS-CoV-2) has spread dramatically due to political inaction and established economical and societal vulnerabilities. ${ }^{1}$ Not surprisingly, countries such as Brazil, Peru, or Ecuador have become large hotspots of COVID-19 in South America with 4,147,794; 689,977; and 110,092 confirmed cases, respectively, as of September $2020 .^{2}$

In contexts of overwhelmed health systems, criteria for COVID-19 patient management should be revised to avoid depletion of hospital resources including laboratory supplies and health personnel. Recently, the World Health Organization (WHO) updated its guidelines to allow hospital discharge based on clinical findings 
as an alternative of RT-PCR positive to negative conversions, ${ }^{3}$ a decision that acknowledged in paper "long-lasting" local practices in low- and middle-income countries. Regardless, multiple institutions across the Americas still request a double RT-PCR negative test to assure a lack of infectiousness, which can be misleading if interpreted plainly as a positive/negative test. ${ }^{4,5}$

Recently, an alternative approach has been suggested to interpret RT-PCR COVID-19 diagnosis based on the cycle threshold $(\mathrm{Ct})$ values, which are correlated with SARSCoV-2 viral load and therefore viral dynamics such as replication and transmissibility. ${ }^{6,7}$ However, there is a lack of consensus of whether a particular threshold for RT-PCR COVID-19 Ct values might be safely used to determine patient infection status with some considering infectious RT-PCR Ct values to those $\leq 24,{ }^{8} \leq 34,{ }^{7,9}$ or $\leq 38 .^{10,11}$

Here, we (1) explored two Ct values (ie, 24 and 33) as avenues for patient diagnosis and follow up in a context of multiple RT-PCR testing in a South American cohort, (2) depict the dynamics of $\mathrm{Ct}$ values at different testing times, and (3) compare the differences of interpretation between $\mathrm{Ct}$ values and plain amplification for COVID-19 diagnosis. We also measured different demographic, clinical, and laboratory variables of the same population to explore their capacity to predict the profile of $\mathrm{Ct}$ values at different testing times.

\section{Patients and Methods}

In this observational case-series, we studied 118 patients hospitalized in a public COVID-19 reference hospital (Hospital General del Sur de Quito) in Quito, Ecuador from March 17th to May 12th, 2020. Deep nasal swab samples were collected using inactivated viral preservative medium (IMPROVIRAL ${ }^{\mathrm{TM}}$ ) and stored at $2-8^{\circ} \mathrm{C}$ at Hospital Carlos Andrade Marín in Quito, Ecuador. All samples were processed within eight hours of collection. We extracted RNA using QIAamp ${ }^{\circledR}$ Viral RNA mini Kit (Qiagen, cat: 52,906) and the RT-PCR was performed using Allplex ${ }^{\mathrm{TM}}$ 2019-nCoV assay (Seegene Inc., Seoul, South Korea) targeting genes E, RdRP, and N, as recommended by the respective manufacturer. If more than one gene was positive, we obtained the average of those observations as a representation of overall $\mathrm{Ct}$ values; on the contrary, if only one gene was available, we used the available value to represent the observation instead of the average. Follow up sample collection was performed regardless of patient status (ie, hospitalized or discharged) and was continued until RT-PCR no-amplification was observed.

\section{Statistical Analysis}

We explored the ability of demographic, laboratory, and epidemiological variables (eg, age, leucocytes, comorbidities, etc) to explain patterns of $\mathrm{Ct}$ values at different testing times. We assessed the normality of distributions and applied a $t$-test or Mann-Whitney-U accordingly to compare different groups. We used Pearson correlation tests to identify any relationship between quantitative variables; also, we dichotomized each result using a threshold of $>33$ to differentiate between non-infectious/infectious cases and explored different parameters using a Chi-square test or Fisher exact test depending on expected values being smaller than five. ${ }^{12}$ We established the value of statistical significance considering an alpha $<0.05$. We repeated all the statistical explorations using a $\mathrm{Ct}$ value of 24 for the first test; we did not explore this threshold in further testing times due to the lack of samples for comparison.

\section{Ethics}

The study was approved by the ethical committee of the Universidad San Francisco de Quito (P2020-023M) and the Ministry of Public Health of Ecuador. We confirm that all patients provided informed consent and that this study was conducted in accordance with the Declaration of Helsinki.

\section{Results}

The median age of the population was 49 years (range: 24 to 91) with 74 males (62.7\%) and 44 females (37.3\%). Seven patients died during hospitalization (5.9\%). The median since symptoms onset to hospital admission was six days (range: 0 to 28; Table 1). The median time from symptom onset to first test was of nine days (range: 0 to 53; Figure 1).

Averaged $\mathrm{Ct}$ values of the three genes from amplifying samples showed increasing values in time with a mean $\mathrm{Ct}$ value of $29.13(\mathrm{n}=61, \mathrm{sd}=5.55)$ for the first test and $34.38(\mathrm{n}=60, \mathrm{sd}=4), 35.52(\mathrm{n}=20, \mathrm{sd}=2.85)$, and 36.12 $(\mathrm{n}=6$, sd $=3.28)$, for the second, third, and fourth tests, respectively (Figure 1). The overall median of no amplification was of 30 days (range: 4 to 69 ) with $50 \%$ of cases labeled as negative between days 22 and 37. Noninfectious $\mathrm{Ct}$ values (ie, >33) were found with a median 
Table I Clinical, Epidemiological, and Laboratory Characteristics of the 1 I 8 Patients Included in the Present Study

\begin{tabular}{|c|c|c|}
\hline Patients & Counts & $\begin{array}{l}\text { Summary } \\
\text { Statistics }\end{array}$ \\
\hline Age & $49 y$ & 24-9I (range) \\
\hline Men & 74 & $62.7 \%$ \\
\hline Women & 44 & $37.1 \%$ \\
\hline Death & 7 & $5.9 \%$ \\
\hline Alive & 111 & $94.1 \%$ \\
\hline Beginning of symptoms to hospitalization & $6 d$ & 0-28 (range) \\
\hline Beginning of symptoms to discharge & $25 d$ & 0-76 (range) \\
\hline First attention to discharge & $20.5 \mathrm{~d}$ & 0-72 (range) \\
\hline $\begin{array}{l}\text { Comorbidities } \\
\text { - Hypertension } \\
\text { - Diabetes mellitus type } 2 \\
\text { - Hypothyroidism } \\
\text { - Chronic kidney disease } \\
\text { - Chronic ischemic cardiomyopathy } \\
\text { - Rheumatoid arthritis } \\
\text { - Lupus } \\
\text { - Hepatic cirrhosis } \\
\text { - HIV }\end{array}$ & $\begin{array}{l}33 \\
22 \\
8 \\
7 \\
3 \\
2 \\
1 \\
1 \\
1 \\
1 \\
1\end{array}$ & $\begin{array}{c}30.28 \% \\
19.8 \% \\
7.2 \% \\
6.3 \% \\
2.7 \% \\
1.8 \% \\
0.9 \% \\
0.9 \% \\
0.9 \% \\
0.9 \% \\
0.9 \%\end{array}$ \\
\hline $\begin{array}{l}\text { Symptomatology } \\
\text { - } \text { Fever } \\
\text { - Dry cough } \\
\text { - Asthenia } \\
\text { - Oyspnea } \\
\text { - Arthralgia } \\
\text { - Productive cough } \\
\text { - Myalgia } \\
\text { - Headache } \\
\text { - Diarrhea } \\
\text { - Runny nose } \\
\text { - Abdominal pain } \\
\text { - Anosmia } \\
\text { - Dysphagia } \\
\text { - Chest pain } \\
\text { - Nausea } \\
\text { - Vomit } \\
\text { - Dysgeusia } \\
\text { - Conjunctivitis } \\
\text { - Dysuria } \\
\text { - Increased frequency of urination }\end{array}$ & $\begin{array}{l}75 \\
57 \\
46 \\
35 \\
29 \\
23 \\
22 \\
21 \\
18 \\
13 \\
13 \\
7 \\
6 \\
6 \\
3 \\
4 \\
4 \\
4 \\
1 \\
1 \\
1\end{array}$ & $\begin{array}{l}67.6 \% \\
51.4 \% \\
41.4 \% \\
31.5 \% \\
26.1 \% \\
20.7 \% \\
19.8 \% \\
18.9 \% \\
16.2 \% \\
11.7 \% \\
11.7 \% \\
6.3 \% \\
5.4 \% \\
5.4 \% \\
2.7 \% \\
3.6 \% \\
3.6 \% \\
3.6 \% \\
0.9 \% \\
0.9 \% \\
0.9 \%\end{array}$ \\
\hline \multicolumn{3}{|l|}{ Laboratory parameters } \\
\hline White blood cells & 6.1 & I.6-6.4I (range) \\
\hline Hemoglobin & 15 & 8.7-49 (range) \\
\hline Hematocrit & 43.45 & 16-55.9 (range) \\
\hline
\end{tabular}

(Continued)
Table I (Continued).

\begin{tabular}{|l|c|c|}
\hline Patients & Counts & $\begin{array}{c}\text { Summary } \\
\text { Statistics }\end{array}$ \\
\hline Platelets & 225 & $2.26-588$ (range) \\
\hline Red blood cells & 4.99 & $3.13-6.32$ (range) \\
\hline Monocytes \% & 7.6 & $0.4-17.3$ (range) \\
\hline Eosinophils \% & 0.2 & $0-20$ (range) \\
\hline Lymphocytes \% & 20.9 & $0.5-61$ (range) \\
\hline Neutrophils \% & 68 & $2.8-94.7$ (range) \\
\hline Basophils \% & 0.4 & $0-2.3$ (range) \\
\hline Glucose & 97 & $56-468$ (range) \\
\hline BUN & 13 & $5-55$ (range) \\
\hline Urea & 25.68 & $0.77-117.7$ \\
(range) \\
\hline Creatinine & 0.81 & $0.45-66$ (range) \\
\hline
\end{tabular}

of 12 days (range: 4-53) since the start of symptoms to the first test (Table 2).

Five patients presented lower $\mathrm{Ct}$ values (ie, $<33$ ) during the third $(n=4)$ and four tests $(n=1)$. One case remained below the $\mathrm{Ct}$ (average $=31.33$ ) on the sixth nasopharyngeal swab test after 53 days of symptoms onset (not shown in Figure 1). Further, while considering the second test, seven patients had a $\mathrm{Ct}$ value $<33$ after 30 days since symptoms onset (Supplementary material). The median $\mathrm{Ct}$ value of gen $\mathrm{E}$ remained below the threshold of 33 up to the third test (Figure 1). Using a less restrictive threshold (ie, Ct of 24), ${ }^{8}$ all but one case might be considered non-infectious on the second test (Figure 1).

Univariate statistical explorations of demographic variables, predictors of severity, and different laboratory parameters were statistically non-significant for the third test and were not calculated for the four test due to lack of samples (Figure 1 and Supplementary material). For the first test, $\mathrm{C}$ reactive protein (CRP) worked as a predictor of infectious versus not infectious patients considering a $\mathrm{Ct}$ value of $33\left(x^{2}=3.691, p=0.033\right)$ with the majority of infectious patients with abnormal CRP measures. Also, for the first test, we found a correlation between platelet counts and $\mathrm{Ct}$ values (Pearson $=0.396, p=0.003$ ). For the second test, we found a negative correlation between age and $\mathrm{Ct}$ values (Pearson $=-0.276, p=0.033$ ) as well as neutrophils and $\mathrm{Ct}$ values (Pearson $=-0.259, p=0.047$ ); 

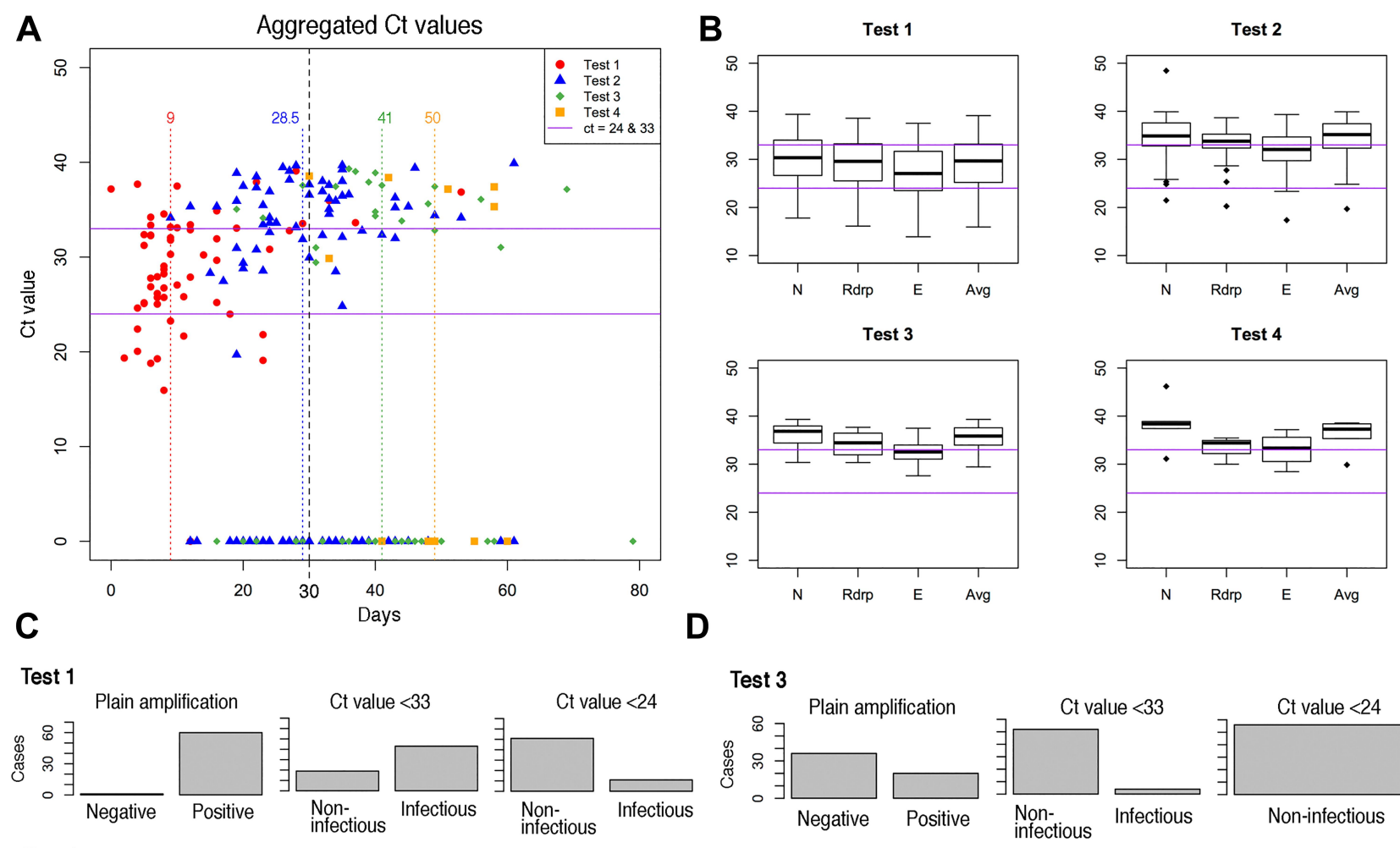

Test 3

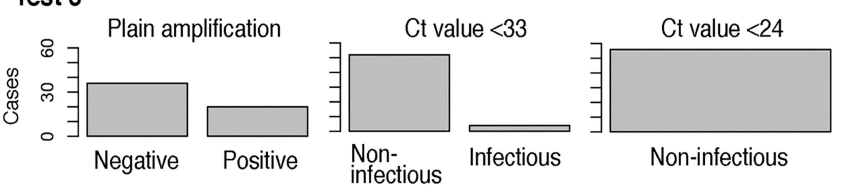

Test 2

Test 4
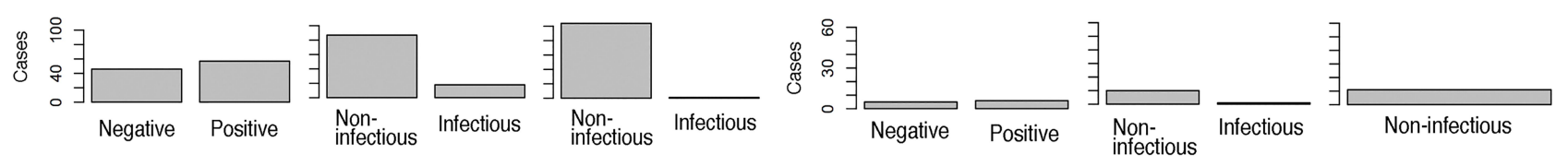

Figure I Cycle threshold (Ct) values obtained at different testing times and COVID-19 status based on RT-PCR plain amplification and Ct values. (A) Distribution of Ct values in relation of symptom to test time (x-axis), depicting the median symptom-to-test time for each testing scenario (vertical lines with numbers representing days) and two $\mathrm{Ct}_{\mathrm{t}}$ thresholds (horizontal lines $=24$ and 33). Day 30 was used previously as a guide for patient discharge and is depicted here for reference (black line). (B) Distribution of Ct values for each testing scenario for the three genes and their average (Avg) as analyzed in this study. (C) The difference of interpretation of COVID-I9 status based on plain amplification, Ct values $<33$, and $<24$ for tests one and two. With a Ct of 24, almost all cases are non-infectious at the second test. (D) Same as $\mathbf{C}$ for test three and four.

moreover, we found a statistical significant difference between patients admitted versus those not admitted to the intensive care unit $\left(x^{2}=6.094, p=0.013\right)$. When using a $\mathrm{Ct}$ value of 24 to differentiate between infectious versus non-infectious patients, we found a statistically significant gender difference $\left(x^{2}=6.579, p=0.04\right)$, which was non-significant when evaluating a $\mathrm{Ct}$ value of 33 (Supplementary material).

\section{Discussion}

In line with recent research, we encourage the use of $\mathrm{Ct}$ values to complement positive/negative SARS-CoV-2 diagnosis and as a potential guide for patient management. ${ }^{13}$ Theoretically, viral replication peaks during the first days of symptoms onset, which argues in favor of presymptomatic transmission. ${ }^{14}$ Here, we recorded $\mathrm{Ct}$ values on different testing scenarios in a cohort of inpatients with a median of 20.05 (range: 0 to 72) hospitalization days, it might be the case that patients diagnosed with milder infections and treated outside the hospital would present higher $\mathrm{Ct}$ values on follow up tests and therefore show a lower transmission risk for the community.

In our study, the median from symptom onset to first testing equals nine days, which argues on a population that has received their first test after a relatively large period. This is a fair representation of the health capacity of Ecuador, which has seen a reduced ability to respond to the pandemic. Furthermore, we expect that the infectious to non-infectious Ct value turnover of the first test shown here ( $=12$ days with a Ct of 33; Table 2) is a feature of a population that presented late on their disease course. Regardless, for the start of the second test, only 18/105 (17.14\%) amplifications had a Ct value below 33 and therefore were labeled as infectious, whereas 87/105 (82.86\%) values were above 33 and were identified as not infectious with the earliest non-infectious second test on day 


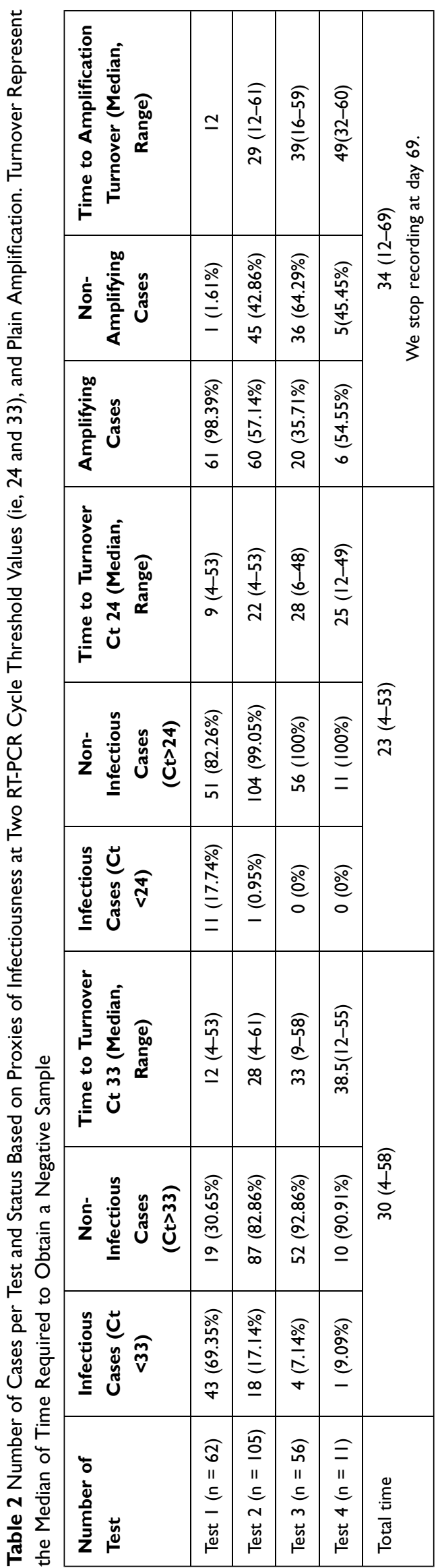

nine after symptoms onset (Figure 1 and Table 2). On the contrary, the $\mathrm{Ct}$ value below 24 identified only one patient as infectious in the second test $(1 / 105 ; 0.95 \%)$ and no infectious cases for the third and four testing scenarios (Figure 1 and Table 2). Using a $\mathrm{Ct}>24$ to categorize patients as non infective might be too optimistic in real-world circumstances where the burden of false negatives might account for further lack of control. $^{8}$

Despite guidelines of the Centers of Disease Control and Prevention (CDC), United States, and the $\mathrm{WHO}^{3,15}$ we identified 13 cases (11\%) with $\mathrm{Ct}$ values $<33$ after day 30 from symptoms onset and therefore labeled as infectious cases (Figure 1, Supplementary material). Although small, this sample of cases might be an important factor for SARSCoV-2 spread and contribute to the persistence of the epidemic by seeding outbreaks with unrecognized sources. ${ }^{16,17}$

In our studied population, only a handful of variables explained the patterns of $\mathrm{Ct}$ values while using a $\mathrm{Ct}$ of 33; specifically, CRP and platelet for the first test, and age, neutrophils, and ICU admission for the second test. On the contrary, only gender was statistically significant in anticipating $\mathrm{Ct}$ values below 24 for the first test. The laboratory parameters including CRP, neutrophils, and platelet count denote a systemic state of infection; the first two have been statistically correlated with $\mathrm{Ct}$ values in other studies. ${ }^{13}$ Similarly, age above 65 years old and ICU admission have been found as predictors of severity in other publications. ${ }^{4,18}$ If these variables are altered on the first examination, $\mathrm{Ct}$ values are more likely to be under 33 and aid diagnosis during the first test, and might anticipate infectiousness during the second test. These and other predictors should be further studied using larger sample sizes to assess their ability to predict COVID-19 status $^{13}$ (Supplementary material). As a semi-quantitative proxy of viral loads, RT-PCR Ct values have been used for evaluating clinical outcomes and transmissibility for acute respiratory tract infections, influenza, and the Middle-East Respiratory Syndrome (MERS), the latter caused by another coronavirus ${ }^{19-21}$ Despite the evidence supporting the role of RT-PCR Ct values on point of care evaluations, ${ }^{13,22}$ variability among different RT-PCR diagnostic kits, and local viral load interpretability, ${ }^{23-25}$ supports its application in tandem with other cues for COVID-19 diagnosis or management.

We acknowledge that our analysis is constrained to samples obtained from deep nasal swab examination and might be an underestimation considering higher concentrations reported in throat swabs or sputum samples; ${ }^{10,26}$ if this is the case, turnover times as depicted in Table 2 might be 
larger complicating indications for lack of infectivity., ${ }^{3,15}$ Sources of uncertainties such as different devices, kits, and techniques might account for local variations and should be considered in order to generalize the present or any other study dealing with RT-PCR Ct values. ${ }^{26-28}$

\section{Conclusions}

As proxies of viral load, $\mathrm{Ct}$ values offer an avenue as an improved criterion for discharge, interpretation of COVID-19 clinical phases, and as tools for individual clinical assessment regarding infectiousness or investment on multiple testing. In this study, $11 \%$ of patients persisted with RT-PCR Ct values $<33$ and were labeled as potential infectious cases for more than 30 days.

\section{Acknowledgments}

DRA was supported by a grant from the National Science Foundation DMS 2028297, also DRA thanks the W.O. G. for writing support.

\section{Author Contributions}

All authors made substantial contributions to conception and design, acquisition or analysis and interpretation of data; took part in drafting the article or revising it critically for important intellectual content; agreed to submit the manuscript to the current journal; gave final approval of the version to be published; and agreed to be accountable for all aspects of the work.

\section{Disclosure}

The authors report no conflicts of interest in this work.

\section{References}

1. Torres I, López-Cevallos DF, Sacoto F. Elites can take care of themselves - comment on COVID-19: the rude awakening for the political elite in low-income and middle-income countries. BMJ Global Health. 2020;5:e003063. doi:10.1136/bmjgh-2020-003063

2. Dong E, Du H, Gardner L. An interactive web-based dashboard to track COVID-19 in real time. Lancet Infect Dis. 2020;20:P533-P534. doi:10.1016/S1473-3099(20)30120-1

3. WHO. Criteria for releasing COVID-19 patients from isolation. World Heal Organ Sci Br. 2020.

4. Gombar S, Chang M, Hogan CA, et al. Persistent detection of SARS-CoV-2 RNA in patients and healthcare workers with COVID-19. J Clin Virol. 2020;129:104477. doi:10.1016/j. jcv.2020.104477

5. Xiao AT, Tong YX, Zhang S. False-negative of RT-PCR and prolonged nucleic acid conversion in COVID-19: rather than recurrence. $J$ Med Virol. 2020;92:1755-1756. doi:10.1002/jmv.25855

6. Tom MR, Mina MJ. To interpret the SARS-CoV-2 test, consider the cycle threshold value. Clin Infect Dis. 2020;71:ciaa619. doi:10.1093/ cid/ciaa619
7. Krupp KF, Madhivanan P, Perez-Velez CM. Should qualitative RT-PCR be used to determine release from isolation of COVID-19 patients? J Infect. 2020;10:46. doi:10.1016/j.jinf.2020.06.030

8. Bullard J, Dust K, Funk D, et al. Predicting infectious SARS-CoV-2 from diagnostic samples. Clin Infect Dis. 2020:ciaa638. Doi:10.1093/ cid/ciaa638.

9. La Scola B, Le Bideau M, Andreani J, et al. Viral RNA load as determined by cell culture as a management tool for discharge of SARS-CoV-2 patients from infectious disease wards. Eur J Clin Microbiol Infect Dis. 2020;39:1059-1061. doi:10.1007/s10096-020-03913-9

10. Yu F, Yan L, Wang N, et al. Quantitative detection and viral load analysis of SARS-CoV-2 in infected patients. Clin Infect Dis. 2020;71:793-798. doi:10.1093/cid/ciaa345

11. Xu K, Chen Y, Yuan J, et al. Factors associated with prolonged viral RNA shedding in patients with COVID-19. Clin Infect Dis. 2020;71:709-806. doi:10.1093/cid/ciaa351

12. Gotelli N, Ellison AM. A Primer of Ecological Statistics. Second ed. Sunderland, MA: Sinauer Associates; 2013.

13. Rao SN, Manissero D, Steele VR, Pareja J. A systematic review of the clinical utility of cycle threshold values in the context of COVID-19. Infect Dis Ther. 2020;9:573-586. doi:10.1007/s40121020-00324-3

14. Wölfel R, Corman VM, Guggemos W, et al. Virological assessment of hospitalized patients with COVID-2019. Nature. 2020;581:465-469. doi:10.1038/s41586-020-2196-x

15. CDC. Discontinuation of isolation for persons with COVID-19 not in healthcare settings (Interim guidance). 2020. Available from: https:// www.cdc.gov/coronavirus/2019-ncov/hcp/disposition-in-homepatients.html. Accessed August 3, 2020.

16. Frieden TR, Lee CT. Identifying and interrupting superspreading events-implications for control of severe acute respiratory syndrome coronavirus 2. Emerg Infect Dis. 2020;26:1059-1066. doi:10.3201/eid2606.200495

17. Li R, Pei S, Chen B, et al. Substantial undocumented infection facilitates the rapid dissemination of novel coronavirus (SARS-CoV-2). Science. 2020;368:489-493. doi:10.1126/science.abb3221

18. Mardani R, Vasmehjani A, Zali F, et al. Laboratory parameters in detection of COVID-19 patients with positive RT-PCR; a diagnostic accuracy study. Arch Acad Emerg Med. 2020;8:e43. doi:10.22037/ aaem.v8i1.632

19. Feikin DR, Alraddadi B, Qutub M, et al. Association of higher MERS-CoV virus load with severe disease and death, Saudi Arabia, 2014. Emerg Infect Dis. 2015;21:2029-2035. doi:10.3201/ eid2111.150764

20. Lalueza A, Folgueira D, Muñoz-Gallego I, et al. Influence of viral load in the outcome of hospitalized patients with influenza virus infection. Eur J Clin Microbiol Infect Dis. 2019;38(4):667-673. doi:10.1007/s10096-019-03514-1

21. Wishaupt JO, van der Ploeg T, Smeets LC, et al. Pitfalls in interpretation of CT-values of RT-PCR in children with acute respiratory tract infections. J Clin Virol. 2020;90:1-6. doi:10.1016/j. jcv.2017.02.010

22. Drew RJ, O'Donnell S, LeBlanc D, et al. The importance of cycle threshold values in interpreting molecular tests for SARS-CoV-2. Diagn Microbiol Infect Dis. 2020;98:115130. doi:10.1016/j. diagmicrobio.2020.115130

23. Vashist SK. In vitro diagnostic assays for COVID-19: recent advances and emerging trends. Diagnostics. 2020;10:202. doi:10.3390/diagnostics10040202

24. Aquino-Jarquin G. The raw Ct values from RT-PCR detection are not viral load quantitation units. Clin Infect Dis. 2020;ciaa830. doi:10.1093/cid/ciaa830

25. Poon KS, Tee NWS. Caveats of reporting cycles threshold from SARS-CoV-2 qualitative PCR assays: a molecular diagnostic laboratory perspective. Clin Infect Dis. 2020; ciaa1399. doi:10.1093/cid/ ciaa1399 
26. Tahamtan A, Ardebili A. Real-time RT-PCR in COVID-19 detection: issues affecting the results. Expert Rev Mol Diagn. 2020;20:453-454. doi: $10.1080 / 14737159.2020 .1757437$

27. Han MS, Byun J, Cho Y, Rim JH. RT-PCR for SARS-CoV-2: quantitative versus qualitative. Lancet Infect Dis. 2020;21:in press. doi:10.1016/S1473-3099(20)30424-2
28. Zou J, Zhi S, Chen M, et al. Heat inactivation decreases the qualitative real-time RT-PCR detection rates of clinical samples with high cycle threshold values in COVID-19. Diagnostic Microbiol Infect Dis. 2020;98:115109. doi:10.1016/j.diagmicrobio.2020.115109

\section{Publish your work in this journal}

Risk Management and Healthcare Policy is an international, peerreviewed, open access journal focusing on all aspects of public health, policy, and preventative measures to promote good health and improve morbidity and mortality in the population. The journa welcomes submitted papers covering original research, basic science, clinical \& epidemiological studies, reviews and evaluations, guidelines, expert opinion and commentary, case reports and extended reports. The manuscript management system is completely online and includes a very quick and fair peer-review system, which is all easy to use. Visit http://www.dovepress.com/testimonials.php to read real quotes from published authors.

Submit your manuscript here: https://www.dovepress.com/risk-management-and-healthcare-policy-journal 